\title{
Trypanosoma cruzi burden, genotypes, and clinical evaluation of Chilean patients with chronic Chagas cardiopathy
}

\author{
Werner Apt ${ }^{1}$ - Arturo Arribada ${ }^{2}$ Inés Zulantay ${ }^{1}$ - Miguel Saavedra ${ }^{1}$. \\ Eduardo Araya $^{1}$ - Aldo Solari ${ }^{3} \cdot$ Sylvia Ortiz $^{3} \cdot$ Katherine Arriagada $^{1}$. \\ Jorge Rodríguez ${ }^{4}$
}

Received: 12 February 2015 / Accepted: 24 April 2015 /Published online: 3 May 2015

(C) The Author(s) 2015. This article is published with open access at Springerlink.com

\begin{abstract}
There are currently no biomarkers to assess which patients with chronic indeterminate Chagas disease will develop heart disease and which will spend their entire life in this state. We hypothetize that the parasite burden and Trypanosoma cruzi genotypes are related to the presence of heart disease in patients with Chagas disease. This study is aimed to investigate the parasite burden and T. cruzi genotypes in chagasic cardiopaths versus chagasic individuals without cardiac involvement according to the New York Heart Association. Patients with chronic Chagas disease, 50 with and 50 without cardiopathy (controls), groups $\mathrm{A}$ and $\mathrm{B}$, respectively, were submitted to anamnesis, physical examination, and electrocardiogram. Echo-Doppler was performed for group A; all important known causes of cardiopathy were discarded. Xenodiagnosis, conventional PCR, and quantitative PCR were performed on patients of both groups. T. cruzi genotyping was done for 25 patients of group A and 20 of group B. The 50 cardiopaths had 80 electrocardiographic alterations, most of them in grade II of the New York Heart Association classification; 49 were classified in grade I by
\end{abstract}

Werner Apt

wapt@med.uchile.cl

1 Laboratorio de Parasitología Básico-Clínico, Programa de Biología Celular y Molecular, Instituto de Ciencias Biomédicas, Facultad de Medicina, Universidad de Chile, Independencia 1027, PO 9183, Santiago 1, Chile

2 Clínica INDISA, Santiago, Chile

3 Laboratorio de Biología Molecular de Parásitos, Programa de Biología Celular y Molecular, Instituto de Ciencias Biomédicas, Facultad de Medicina, Universidad de Chile, Santiago, Chile

4 Escuela de Salud Pública, Facultad de Medicina, Universidad de Chile, Santiago, Chile
Echo-Doppler, and only one patient was in grade III. The difference in average parasitemia in patients of groups A and B was not significant. The most frequent $T$. cruzi DTU found was $\mathrm{TcV}$. The parasite burden and genotype of the groups with and without cardiopathy were similar.

Figure 2 Chronic Chagas cardiopathy microaneurism of left ventricle. Cineangiography

Keywords Chagasic cardiopaths $\cdot$ Trypanosoma cruzi DTUs · Parasite burden · Genotypes

\section{Introduction}

Chagas disease $(\mathrm{ChD})$ is a pathology that affects about 6-7 million people in the American continent (WHO 2015) where it is autochthonous and has been introduced into Europe, Asia, and Oceania through human migration (Basile et al. 2011; Molina-Berríos et al. 2013). There are 80-100 million people at risk of acquiring the disease (Salvatella 2012).

$\mathrm{ChD}$ is currently one of the most important neglected diseases. It represents the fourth disease in importance in years lost due to incapacity (Tarleton and Curran 2012; Apt et al. 2013). Two periods characterize the natural evolution of the disease, acute and chronic; the latter with persistent infection in the heart and adipose tissue (Wen et al. 2014) may be latent, indeterminate, or determinate (Coura and Viñas 2010; Rassi et al. 2010). Less than $5 \%$ of the individuals in the acute period develop symptomatology, especially in children. Fifty to seventy percent of chronic chagasic cases have a latent or indeterminate stage which lacks clinical symptoms and with normal routine clinical laboratory tests; $10-30 \%$ develop cardiac pathology and $8-10 \%$ digestive commitment. Without doubt, chronic Chagas cardiopathy is the worst form of the disease, due to its morbidity and mortality (Rassi et al. 2010). 
Young people with $\mathrm{ChD}$ and normal ECG have periods of survival nine times greater than chagasic persons of the same age with an abnormal electrocardiogram (Rassi et al. 2009). Patients with cardiomyopathy due to Trypanosoma cruzi and cardiac insufficiency have worse prognosis than those heart myopathies with decompensated heart failure due to other aetiologies $(69.2 \mathrm{v} / \mathrm{s} 47.9 \%$ mortality at 1 year, respectively) (Silva et al. 2008). The outcome of Chagas cardiomyopathy is worse than idiopathic cardiomyopathy (Barbosa et al. 2011). Chagas cardiomyopathy presents a higher frequency of stroke compared to a non-Chagas cohort (Da Matta et al. 2012). The annual cost of Chagas cardiomyopathy, including both health costs and disability-adjusted annual losses, exceeds that which is originated by cervical uterine cancer and rotavirus, according to simulated computer models (Lee et al. 2013). About $50-60 \%$ of the people with the indeterminate form remain in this asymptomatic state for life. For example, Berenice, the first patient of Carlos Chagas (discoverer of the disease) whose $\mathrm{ChD}$ diagnosis was performed at age of two, died at 82 years of age without presenting any symptomatology due to $\mathrm{ChD}$ in her life. In Brazil and Chile, $1-2 \%$ of the patients with indeterminate chronic $\mathrm{ChD}$ develop cardiopathy each year.

It is very important to know which infected subjects will develop heart disease and who will not, to apply etiologic therapy to the former and not to all the patients with indeterminate chronic $\mathrm{ChD}$. To date, no biomarkers are available to answer this question (Venegas et al. 2010; Requena-Méndez et al. 2013; Urbina 2015). To determine whether the parasite burden and T. cruzi genotypes are related to the presence of heart disease in patients with $\mathrm{ChD}$, we conducted this study aimed to investigate the parasite burden and $T$. cruzi discrete typing units (DTUs) TcI-TcVI in chagasic cardiopaths versus chagasic individuals without cardiac involvement according to the New York Heart Association (NYHA) (1994; Cura et al. 2012).

\section{Material and methods}

\section{Population}

Adult patients with chronic $\mathrm{ChD}$ of the IV region (Coquimbo), Chile from the localities of Illapel and Salamanca (Choapa province) and Combarbalá (Limarí province), hyperendemic areas located between $29^{\circ} 02^{\prime}$ and $32^{\circ} 16^{\prime}$ South latitude, were examined twice a year in outpatient clinics (rural patients) and hospitals (urban patients) by our investigation group. They were submitted to anamnesis, physical examination, and ECG of twelve leads. The patients were divided into two groups according to whether or not they presented ECG alterations. Fifty individuals with chronic chagasic cardiopathy were randomly selected (group A) and 50 without cardiopathy (group B). Echo-Doppler was performed on the patients of group A to eliminate other important known causes of cardiopathy, hypertension, valve disease, atherosclerosis, myocardiopathy, and congenital malformations. Xenodiagnosis (XD), conventional PCR (cPCR), and quantitative PCR (qPCR) for T. cruzi were performed on patients of both groups. Genotyping of T. cruzi was successful in 25 patients of group A and 20 of group B.

\section{Ethics statement}

The participation of the patients was under Informed Consent approved by the Ethical Committee of the Faculty of Medicine of the University of Chile (Protocol No. 048-11). Informed consent from patients was given in written form.

\section{Conventional serology}

In the IIF test, epimastigote forms of T. cruzi, Tulahuén strain, were used as antigens. They were cultured in Diamond medium supplemented with $5 \%$ fetal bovine serum maintained at $28{ }^{\circ} \mathrm{C}$. In the exponential growth phase, parasites were collected by centrifugation at $1300 \mathrm{~g}$ for $10 \mathrm{~min}$ at $4{ }^{\circ} \mathrm{C}$ (Maya et al. 2007). Titers equal or superior to $1 / 20$ dilutions were considered positive. In each determination, positive and negative controls from chagasic and non-chagasic individuals were included. An ELISA test was applied using Chagatek ELISA (BioMerieux, France). The optical density corresponding to the cutoff value was determined by the average of the negative control plus 0.100. The ELISA OD values for the negative controls in the different assays fluctuated between 0.001 and 0.09 . The plate was read in a spectrophotometer PHOMO of Autobio, by indications of Micro-Elisa System.

\section{Conventional xenodiagnosis}

The colony of Triatoma infestans used in xenodiagnosis (XD) has been maintained in our laboratory for 50 years fed on chickens, which are normally refractory to $T$. cruzi (Schenone 1999). XD was applied using two cylindrical wooden boxes each containing seven uninfected third or fourth instar nymphs of $T$. infestans starved for a period of 3-4 weeks. The insects of the cages were fed by patients and then maintained at $27{ }^{\circ} \mathrm{C}$ and $70 \%$ relative humidity without further feeding. After 30, 60, and 90 days of incubation, the rectal contents of triatomines fed on each patient were obtained by slight abdominal compression in a biologically secure hood, for examination under an optical microscope at $\times 40,100$ fields were observed to detect mobile trypomastigotes or epimastigotes of $T$. cruzi. The criteria to determine a negative $\mathrm{XD}$ was the absence of mobile forms of T. cruzi in the three periods of microscopic observation (30, 60, and 90 days) (Saavedra et al. 2013). 


\section{Electrocardiographic tracing}

The patients were evaluated by a twelve-lead electrocardiogram. Each electrocardiographic trace included the following parameters: P axis, P duration, P-R space, R-R space, R space, QT value, QTc calculation, QRS axis, T axis, ventricular gradients, RV1 intrensicoide deflexion, SV1, RVS, Sokolow index, and an electrocardiographic diagnosis. The final interpretation of this test data was performed by a specialist cardiologist following the double blind protocol recommended by the World Health Organization; the investigator analyzing the ECG traces was unaware of the status of the patients (Maguire et al. 1982).

\section{Echo-Doppler}

The Echo-Doppler was performed in Baquedano Square Medical Image Centre of Santiago, Metropolitan Region, Chile, with a latest generation Philips apparatus. The following parameters were measured with bi-dimensional M mode: systolic diameter of left ventricle, diastolic diameter of left ventricle, septum of left ventricle, posterior wall of left ventricle, left auricular size, hypertrophic sign of left ventricle, mass of left ventricle, and ejection fraction of left ventricle. The Doppler measurements allowed the determination of the status of the different valves and the presence of reflux. The final interpretation of this test was performed by a cardiologist specialist in echography.

\section{DNA extraction}

Five milliliters of venous blood of each patient was mixed with the same volume of a $6 \mathrm{M}$ guanidine hydrochloride $0.2 \mathrm{M}$ EDTA pH 8.0 solution, incubated at $98^{\circ} \mathrm{C}$ for $15 \mathrm{~min}$ to nick DNA of $T$. cruzi minicircles and stored at $4{ }^{\circ} \mathrm{C}$. DNA extraction was performed in $200 \mu \mathrm{L}$ of the samples mixture, using the QIAamp ${ }^{\circledR}$ DNA Blood Mini Kit (Qiagen, Valencia, $\mathrm{CA}$ ) according to the manufacturer's instructions. The purified DNA was maintained at $-20^{\circ} \mathrm{C}$ until use.

\section{Conventional PCR}

Conventional PCR (cPCR) was performed in triplicate using oligonucleotides 121 and 122, which anneal to the four conserved regions present in T. cruzi minicircles (Degrave et al. 1988), to obtain $330 \mathrm{bp}$ amplicons. Each sample was tested in a final volume of $20 \mu \mathrm{L}$ including $5 \mu \mathrm{L}$ of extracted DNA. The final concentrations of the reagents were as follows: $2.5 \mathrm{mM} \mathrm{MgCl}_{2}, 0.2 \mathrm{mM}$ of each dNTP, $0.5 \mu \mathrm{M}$ of each primer, and 1 unit GoTaq DNA polymerase (Promega Corp., USA). The amplification program was performed in a TC412 thermal cycler (Techne, UK) which included an initial denaturation at $98^{\circ} \mathrm{C}$ for $1 \mathrm{~min}$ and $64^{\circ} \mathrm{C}$ for $2 \mathrm{~min} ; 33$ cycles of $94^{\circ} \mathrm{C}$ for $1 \mathrm{~min}, 64^{\circ} \mathrm{C}$ for $1 \mathrm{~min}$ and $72^{\circ} \mathrm{C}$ for $1 \mathrm{~min}$, and a final extension at $72^{\circ} \mathrm{C}$ for $10 \mathrm{~min}$. Each experiment included two negative PCR controls: water instead of DNA and DNA of non-chagasic patients. As positive control purified DNA of T. cruzi Tulahuén strain was used. Amplification products were analyzed by electrophoresis in a $2 \%$ agarose gel and visualized after staining with RedGel (Biotium Inc.). Five microliter Bench Top 100 bp DNA ladder (Promega Corp.,USA) was incorporated. A positive result for $\mathrm{CPCR}$ was the presence of a $330 \mathrm{bp}$ band specific for T. cruzi minicircles.

\section{Quantitative PCR for Trypanosoma cruzi (qPCR)}

The TaqMan ${ }^{\circledR}$ detection system was applied in a Stratagene $\mathrm{MX} 3000 \mathrm{P}^{\mathrm{TM}}$ thermocycler (Agilent Technologies) under conditions suggested by the manufacturer and using primers of DNA satellite Cruzi 1, Cruzi 2, and Cruzi 3 (Schijman et al. 2011). The reaction mixture consisted of $2 \mu$ of the sample to be investigated, $10 \mu \mathrm{l}$ Brilliant Multiplex QPCR Master mix (Stratagene), $0.5 \mu \mathrm{l}$ of a 1:500 dilution of a reference dye (ROX), $0.5 \mu \mathrm{l}$ each of Cruzi 1, and Cruzi 2, $0.2 \mu \mathrm{l}$ Cruzi 3, $0.2 \mu \mathrm{lBSA}(100 \mathrm{x})$ and $6.1 \mu \mathrm{l}$ Molecular Biology Grade Water (Mo Bio Laboratories Inc.) in a final volume of $20 \mu \mathrm{l}$. To obtain a standard curve to perform the quantification, we used a stock of epimastigote forms of $T$. cruzi, Tulahuen strain. The total DNA quantification was carried out using AccueBlue ${ }^{\mathrm{TM}}$ High Sensitivity dsDNA Quantitation kit (Biotum Inc.) and the qPCR instrument Mx3000P ${ }^{\text {TM }}$ (Stratagene, Agilent Technologies Inc.) as detector devices according to Bravo et al. (2012). A T. cruzi DNA concentration equivalent to $1 \times 10^{6}$ epimastigotes $/ \mathrm{ml}$ was adjusted, considering that 1 parasite cell contains $200 \mathrm{fg}$ of DNA(Duffy et al. 2009). The DNA was diluted $1: 10$. The standard curve of $T$. cruzi was maintained at $-20{ }^{\circ} \mathrm{C}$ until use.

The controls used for qPCR-T. cruzi were as follows: negative control, DNA of a non-chagasic patient confirmed by serology (IIF and ELISA), evaluated previously with qPCR equipment and positive controls, DNA of an individual with $\mathrm{ChD}$ with confirmed parasitemia by PCR and evaluated previously in qPCR equipment. Control mixture: $20 \mu \mathrm{l}$ of mixture reaction for $T$. cruzi (without the sample under study). Water control: $2 \mu \mathrm{l}$ of water free of nucleases (Mo Bio Laboratories Inc.) (replacing the study sample). The control mixture and water control are useful to evaluate contamination in the preparation of the mixture reaction or unspecific qPCR reactions. Each point of the standard curve was performed in triplicate. The samples and controls were included in duplicate. As an internal control of extraction and inhibition of qPCR, we used chromosome 12 (X12) (Bravo et al. 2012). X12 primers were designed by N. Jullien using the AmplifX v.1.5.4 software, and compared with Nucleotide BLAST (National Library of Medicine) to discount any other unspecific amplification (N. Nazal, personal communication). The 
N1X12 forward (5'-GCTGGCTAGACTGTCAT-3') and N2X12 reverse (5'-CTTTGCCGTTGAAGCTTG-3') and N3X12 probe (N3X12 5'-/56-FAM/TGGGACTTC/ZEN/ AGAGTAGGCAGATCG/3IABkFQ/-3') primers were used. The standard curve for X12 was prepared with a pool of human genomic DNA of five non-chagasic individuals diluted $1 /$ 5 in elution buffer. The reaction mixture was composed of $10 \mu \mathrm{l}$ Brilliant Multiplex QPCR Master Mix, $0.5 \mu \mathrm{l}$ of a 1:500 solution of Reference Dye (ROX), $2 \mu$ each N1/N2, $0.8 \mu \mathrm{l} \mathrm{N} 3,0.2 \mu \mathrm{l}$ BSA (100x), $2.5 \mu \mathrm{l}$ Molecular Biology Grade water (Mo Bio Laboratories, Inc.), and $2 \mu 1$ of DNA isolate in a final reaction volume of $20 \mu$ l. The thermals profiles of qPCR-T. cruzi and qPCR-X12 included 10 min of preincubation at $95{ }^{\circ} \mathrm{C}$ and 40 amplification cycles $\left(95^{\circ} \mathrm{C}\right.$ for $15 \mathrm{~s}, 60^{\circ} \mathrm{C}$ for $1 \mathrm{~min}$ ). The measurement of emitted fluorescence was performed at $60{ }^{\circ} \mathrm{C}$ at the end of each cycle. The MxPro v4.1 (Agilent Technologies) software delivered automatically the parasites $/ \mathrm{ml}$ data.

\section{Hybridization assays}

T. cruzi genotyping was performed twice by DNA blot analysis of DNA minicircle amplicons in 75 patients. In 21 of them, the concentration of PCR products was below the minimum required for hybridization tests. The primers for probe generation were CV1 (5'-GATTGGGGTTGGAGTACTAT$3^{\prime}$ ) and CV2 (5'-TTGAACGGCCCTCCGAAAAC-3'), which produced a 270-bp fragment. These fragments were further digested with restriction endonucleases Sau96I and ScaI (Fermentas, Ontario, Canada) to obtain a 250-bp band and remove all sequences from the minicircle constant region. Finally, the probes sp104c11 (TcI), CBBc13 (TcII), NRc13 $(\mathrm{TcV})$, and $\mathrm{v} 195 \mathrm{cl} 1 \mathrm{(TcVI})$ were labeled using the random primer method with $\left[\alpha_{-}{ }^{32} \mathrm{P}\right]$ dATP. The membranes were pre-hybridized in a solution of $6 \times \mathrm{SSC}$ and $1 \mathrm{mM}$ EDTA $\mathrm{pH}$ 7.4 with salmon sperm DNA at $55^{\circ} \mathrm{C}$. The membranes were hybridized overnight with the labeled probe at $55^{\circ} \mathrm{C}$ in the same solution and then washed in high-stringency conditions $\left(0.1 \times \mathrm{SSC}\right.$ and $0.1 \times \mathrm{SDS}$ at $\left.68^{\circ} \mathrm{C}\right)$. The membranes were exposed for $1-4 \mathrm{~h}$ in a Molecular Imager (FX Bio Rad Laboratories, Hercules, CA). This method has been validated by hybridization with the probes constructed by PCR amplification of $T$. cruzi DNA from different kDNA DTU typing (Veas et al. 1991; Brenière et al. 1995, 1998; Solari et al. 2001; Rodríguez et al. 2009; Arenas et al. 2012). The hybridization profiles were analyzed to compare the intensity of the ethidium bromide-stained bands in each membrane with the presence of the radioactive bands obtained with each probe. The specificity of the probes was tested in hybridization controls against DNA of the probes themselves. The profiles of radioactive hybridization signals with multiple probes are indicative of mixed infections with several genotypes of T. cruzi.

\section{Statistical analysis}

The data were analyzed using the SPSS program version 19.0. The description of the data was performed by tables, arithmetic mean, mode, standard deviation, and amplitude of the variable. Chi square was applied for group comparison of qualitative variables. In the case of quantitative variables, Levene tests were applied to evaluate the homoscedasticity and Student's $t$ test to evaluate the average burden. A significance level of 0.05 was used.

\section{Results}

\section{Age, gender, and geographical origin of groups A and B}

Ages of the individuals of group A ranged from 30 to 81 years, average 58.3. Sixty percent of the patients were women. Most patients were from Combarbalá (58\%), and $70 \%$ lived in rural zones. In group B, the average age was 49.6 years, ranging from 20 to 76 years old. Eighty percent of the patients were women. Most patients were from Illapel (42\%), and $66 \%$ lived in rural zones. The patients of groups A and B were examined in the outpatient clinics and hospitals where they live between 2011 and 2013. The average age of group A is significantly greater that of group B $(t=3.39 ; p=0.001)$ (Tables 1 and 2).

\section{Serological results}

The titers of the IIF IgG were between $1 / 40$ and $1 / 1280$, and the OD of the ELISA was 0.17 to 2.575 . The OD values from the ELISA and titers from the IIF tests demonstrated broad agreement for patients exhibiting both strong and weak serological responses, in agreement with previous studies (Umezawa et al. 1996; Luquetti et al. 2009) (Tables 1 and 2).

\section{Parasite burden and genotypes}

The averages obtained in the standard curves of qPCR for T. cruzi for the parameters were as follows: correlation coefficient $\left(R^{2}\right)$ 1.00, slope (Y) 3.46, and efficiency (Eff) 94.45. The $\mathrm{Ct}$ averages for each point of the standard curve were as follows: $10^{5}$ parasites $/ \mathrm{ml} \mathrm{Ct:} 16.59 ; 10^{4}$ parasites $/ \mathrm{ml} \mathrm{Ct}$ : 19.97; $10^{3}$ parasites/ml Ct: $23.47 ; 10^{2}$ parasites/ml Ct: 27.11 ; $10^{1}$ parasites $/ \mathrm{ml} \mathrm{Ct:} 30.65 ; 1$ parasites $/ \mathrm{ml} \mathrm{Ct:} 33.47 ; 10^{-1}$ parasites $/ \mathrm{ml} \mathrm{Ct:} \mathrm{36.71.} \mathrm{In} \mathrm{the} \mathrm{cases} \mathrm{of} \mathrm{group} \mathrm{A}$, the parasite burden fluctuated between 32.99 and 39.99 , corresponding to 2.38 and 0.009 parasites $/ \mathrm{ml}$, respectively. The average $\mathrm{Ct}$ in the 50 patients of this group was 36.88. In the cases of Group $\mathrm{B}, \mathrm{Ct}$ fluctuated between 33.88 and 39.92 , corresponding to 1.27 and 0.01 parasites $/ \mathrm{ml}$, respectively. The average $\mathrm{Ct}$ in the 50 patients of this group was 37.23. In the standard curve, the 


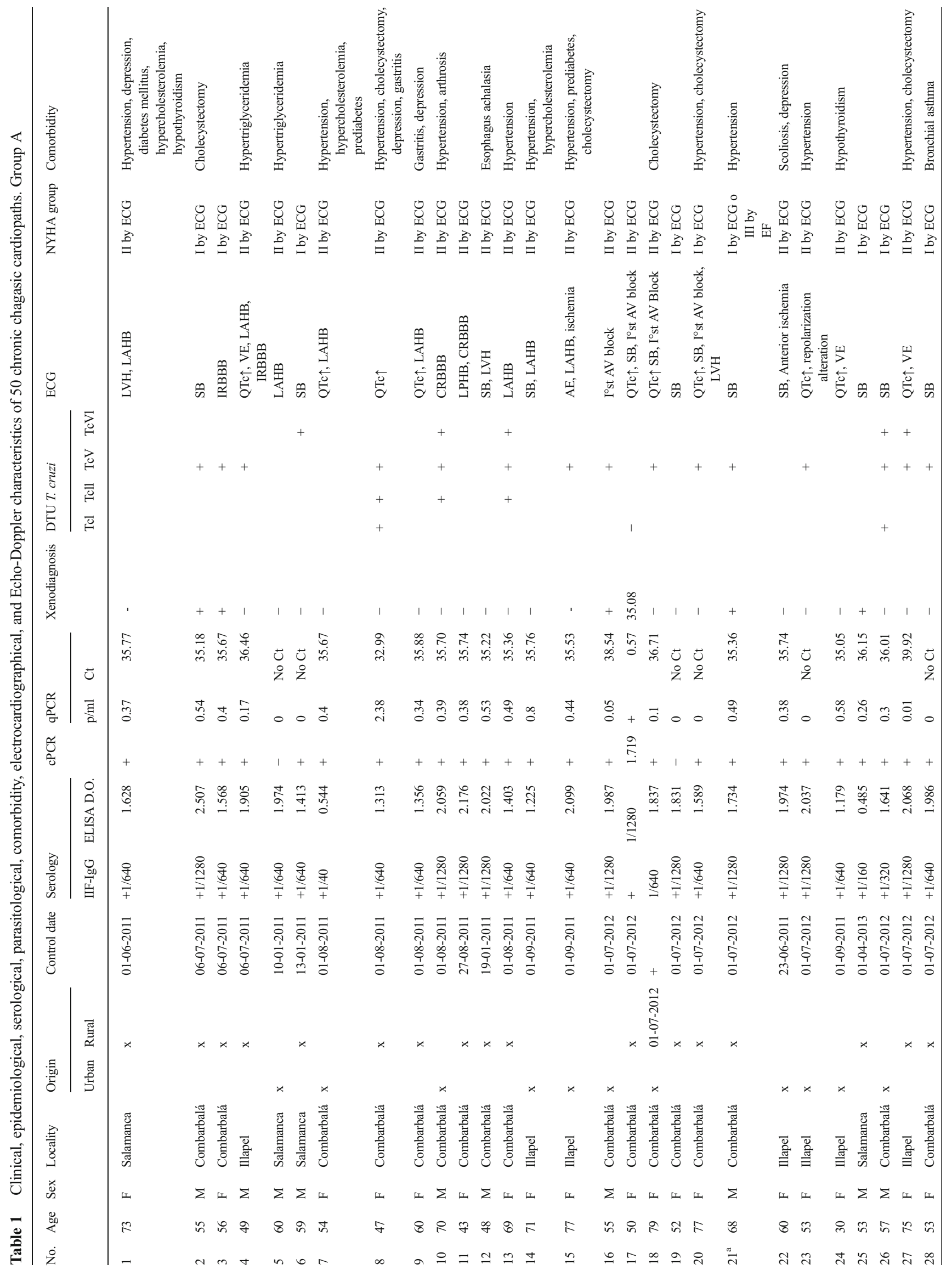














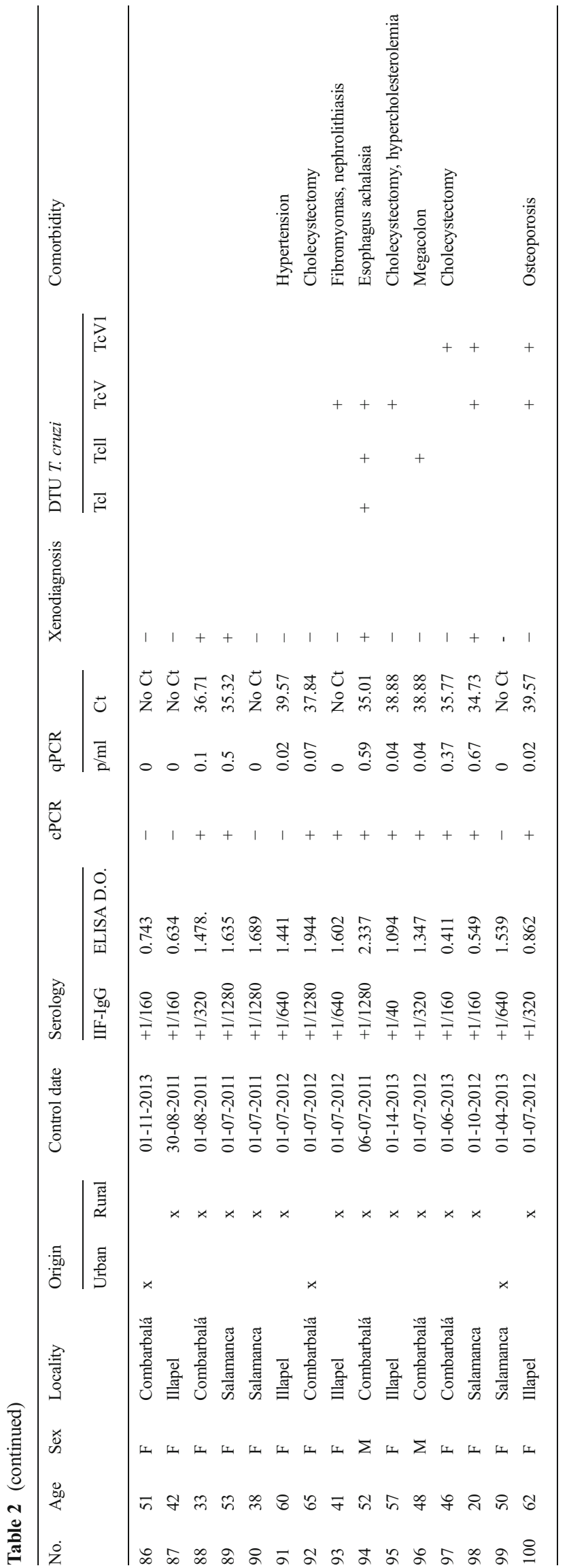

last point corresponds to 0.1 parasites $/ \mathrm{ml}$. Automatic interpolation occurred where the T. cruzi parasitemia estimated by qPCR was less than 0.1 parasites $/ \mathrm{ml}$ using the MxPro v4.1 (Agilent Technologies) software package. Average levels of parasites did not differ significantly between patients of groups $\mathrm{A}$ and $\mathrm{B}$.

In group $\mathrm{A}$, the parasitological evaluation demonstrated that $\mathrm{CPCR}$ and qPCR were positive in $40(80 \%)$ and 43 ( $86 \%$ ) of the cases, respectively, nevertheless XD was positive only in 10 cases $(20 \%)$. In group B, without cardiopathy, cPCR and qPCR were positive in $35(70 \%)$ and $35(70 \%)$ of the cases, respectively, nevertheless XD was positive only in 10 cases $(20 \%)$.

The number of patients with positive qualitative and quantitative amplification of parasite DNA (cPCR and qPCR) was greater in group A compared to group B, $40 \mathrm{v} / \mathrm{s} 35$ and $45 \mathrm{v} / \mathrm{s}$ 35 cases, respectively, but without statistical significance. Of the 100 individuals included in this study, 75 were cPCR positive. Of these, 45 were hybridized for genotyping. In the other 30 samples, T. cruzi DNA was insufficient for (21 samples) or were not recognized by the probes used (9 samples). According to representative results (Fig. 1), the most frequent T. cruzi DTU was TcV, but also TcI, TcII, TcVI, and mixtures up to three were circulating in peripheral blood (Table 3).

\section{Electrocardiographic and Echo-Doppler alterations of group A}

The 50 cardiopaths of group A had 80 electrocardiographic alterations (Table 1). According to the NYHA classification, group A was divided into two sub-groups. In sub-group I, the 17 patients showed electrocardiographic alterations of grade I NYHA classification (1994; Andrade et al. 2011). There were 15 cases, 9 men and 6 women aged 38 to 81 years, who showed sinus bradycardia from 41 to $58 \mathrm{pm}$ in the ECG tracing. In two others, one man of 46 and a woman of age 56 years right bundle branch block was incompletely blocked. In subgroup II, 14 women and 6 men had more than one electrocardiographic alterations. In eight cases, six women and two men aged 48 to 79 years had sinus bradycardia ranged. Three of these women had first-degree A-V block and prolonged QTc interval associated with bradycardia, in two cases and left ventricle hypertrophy in the others. One women had left anterior hemiblock, another had bradycardia in association with prolonged QTc interval, and the last woman showed ischemia in association with bradycardia. One man had left ventricle hypertrophy associated with bradycardia and the others prolonged QTc interval. Ten cases, 7 women and 3 men aged 49 to 77 years showed left anterior hemiblock, alone in 3 cases, one in association with left ventricle hypertrophy and in another two with prolonged QTc time, ventricular extrasystole and incomplete right bundle branch block, in association with prolonged QTc time in one case, in one with myocardial 
Fig. 1 Trypanosoma cruzi cPCR amplicons stained with ethidium bromide (A). Hybridization profiles obtained with genotypes specific probes corresponding to TcI (B), TcII (C), TcV (D), and TcVI (E). The 330 base pair (bp) product represents a positive assay. Cases 1-50: cardiopaths; cases 51-100: no cardiopaths

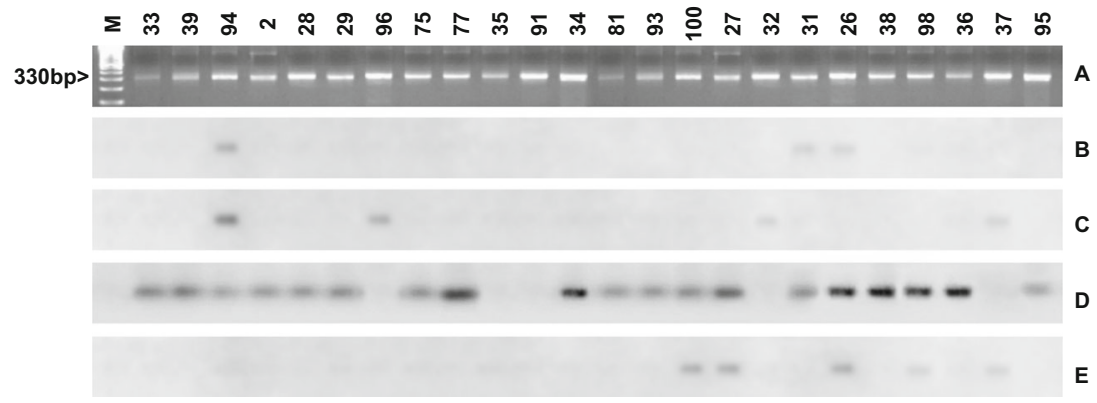

Cases 1-50: cardiopaths; cases 51-100: no cardiopaths ischemia and auricular extrasystole, one with complete right bundle branch block and prolonged QTc interval and the last with sinus bradycardia (already mentioned). Prolonged QTc time appeared in 17 cases ( 12 women aged 31 to 79 years and 4 men aged 36 to 49 years). This was an isolated finding in three cases; in the other 14, it was associated. First A-V block was present in four patients, isolated in one, and the other three were associated (Table 1). Most of the patients of group A were in grade I or II of the NYHA classification. The EchoDoppler was normal in 49 cases. One patient (number 21) with sinus bradycardia had a low ejection fraction (56\%) (Table 1). Gender and cardiopathy were not associated.

\section{Comorbility}

In relation to comorbidity, 34 (68\%) patients of group A and 25 (50\%) of group B did have an associated pathology. This difference is not statistically significant $(\mathrm{z}=1.43, \mathrm{p}=0.0764)$. The most frequent concomitant pathology in groups $\mathrm{A}$ and $\mathrm{B}$ was hypertension (58.8 and $48 \%$, respectively), followed by hypercholesterolemia in group A (29.4\%) and cholecystectomy in group B (36\%) (Tables 1 and 2).

\section{Discussion}

The majority of the patients of group A (70 \%) and group B $(66.0 \%)$ live in rural zones, where they have more contact with infected vectors and whose houses are appropriate for the development of the vectors (Briceño-León 1990; Schofield 1994; Gomes et al. 2013). This area is currently free of T. infestans, the most important domiciliary vector of Chagas disease (OPS/OMS 2000). Comparing the age groups (Tables 1 and 2) shows that there are more older people in group A (above 70 years) and more younger people in group $\mathrm{B}$ (under 30 years), and that the average age of group A, 57.8 years, is significantly greater than that of group B, 49.6 years. These results are consistent, since Chagas cardiopathy requires a prolonged period to develop (Elizari 1999; Rassi et al. 2009; Morillo 2013). In the present study, the cardiopathy increased with age. Females predominated in both groups (60 and $80 \%$ group A and B, respectively) due to the greater attendance of women in clinical controls for Chagas disease, while their husbands were working and the greater willingness of women from endemic zones to transfer to the Metropolitan Region to perform cardiac Echo-Doppler. No association between sex and cardiopathy was observed; similar results were obtained by other investigators (Pereira et al. 1990; Silva et al. 2007), but are discordant with Basquiera et al. (2003), who reported more males with Chagas cardiomyopathy.

The results of the parasitological study of group A showed that the percentages of detection of $T$. cruzi by XD, cPCR, and qPCR were 20,80 , and $86 \%$, respectively. In the group $B$, the percentages were 20,70 , and $70 \%$, respectively. XD was positive in $20 \%$ of groups $\mathrm{A}$ and $\mathrm{B}$, concordant with literature where the sensitivity in chronic Chagas patients fluctuated between 5.3 and 50 \% (Basso and Moretti 1984; Pereira et al. 1992; Siqueira-Batista et al. 1994). Three cases were XD (+) and PCR (-) (2 in group A and 1 in group B). Except for these, there was no discordance between XD and qPCR.

The results of sensitivity obtained by cPCR are also concordant with other studies on this period of the disease, with percentages between 43 and 75.2\% (Hidron et al. 2010; Gilber et al. 2013). In this study, the concordance between cPCR and qPCR in groups A and B was 78 and $84 \%$, respectively. The seven cases of group A and 4 of group B, with positive $\mathrm{qPCR}$ and negative $\mathrm{cPCR}$, presented loads very close to the lower limit of the dynamic range established (between 0.009-0.04 parasites $/ \mathrm{ml}$ ). The quantification limit of qPCR for $T$. cruzi in our laboratory is 0.01 parasites $/ \mathrm{ml}$. Four cases

Table 3 Genotypes of Trypanosoma cruzi in 25 cardiopaths group A and 20 non-cardiopaths group B of Chile

\begin{tabular}{lrrr}
\hline & & Group A & \multicolumn{1}{c}{ Group B } \\
\hline Infection & Single & $18(72 \%)^{\mathrm{a}}$ & $15(75 \%)^{\mathrm{c}}$ \\
& Mixed & $7(28 \%)^{\mathrm{b}}$ & $5(15 \%)^{\mathrm{d}}$ \\
Total & & 25 & 20
\end{tabular}

The most frequent DTU was the following: ${ }^{\mathrm{a}} \mathrm{TcV}(15$ cases $),{ }^{\mathrm{b}} \mathrm{TcV}-\mathrm{TcVI}-$ TcII ( 2 cases $),{ }^{\mathrm{c}} \mathrm{TcV}$ (10 cases), and ${ }^{\mathrm{d}} \mathrm{TcV}-\mathrm{TcVI}$ ( 2 cases $)$ 
of group A and four cases of group B had positive cPCR and negative qPCR. The sensitivity of kDNA cPCR in our laboratory with $5 \mathrm{ml}$ of peripheral blood, if there is at least one intact parasite, the detection limit is 0.2 genomic equivalents (Schijman et al. 2003). This discordance was probably due to the use of different parasite targets, kDNA for cPCR and nuclear satellite DNA for qPCR (Moreira et al. 2013). No significant difference was found between average parasite burden in patients of group A and B, nevertheless in group B, there was a higher proportion of cases without parasites detectable by qPCR (15 against 7 ), and in group A, two cases were found with more than two parasites $/ \mathrm{ml}$ of blood. This result differs from (Mosca et al. 1985) who demonstrated higher parasitemia by XD in cardiopaths than chronic chagasic patients without cardiopathy. It is also important to consider that parasitemia does not always represent the parasite burden; tissue parasite burden represents more exactly $T$. cruzi burden of chagasic patients (Vago et al. 2000; Valadares et al. 2008). Another study concluded that parasitemia does not correlate with the number of alterations detected in the electrocardiographic tracing (Tarleton and Curran 2012).

T. cruzi DTUs circulating in cardiopaths and noncardiopaths appear to be the same. $\mathrm{TcV}$ was the most abundant and TcI the least frequent DTU detected in these patients, even though other not identified DTUs are also circulating in some patients. The presence of mixed DTUs (11/21) and undetermined DTUs $(9 / 21)$ were also reported in a previous survey (Muñoz et al. 2013)

Our results agree with an experimental survey in mice inoculated with three main $T$. cruzi genotypes, in which all resulted with cardiomyopathy (De Diego et al. 1998) and $\mathrm{TcV}$, the most frequent genotype in Argentina (Burgos et al. 2007; Cura et al. 2012). They differ from the genotypes more frequently observed in patients with cardiomyopathy, TcI in Colombia and Venezuela, TcII in Brazil (Ramírez et al. 2010; Segovia et al. 2013) Therefore, ECG alterations are not related to the number or genotype of parasites. In addition, mild cardiopathies of Colombia and Argentina had 20 times higher parasite loads than patients from Brazil with severe cardiopathy (Moreira et al. 2013).

The diagnosis of Chagas cardiomyopathy was made based on clinical examination, results of the ECG and cardiac Echo-Doppler, which allowed ruling out the most important cardiomyopathies of other etiologies. In relation to comorbidity, hypertension was the most frequent pathology observed in both groups (Tables 1 and 2). In patients of group A who had hypertension and/or hypercholesterolemia, the cardiopathy was due to $\mathrm{ChD}$ and not to hypertension, as the ECG showed no left ventricular hypertrophy and the cardiac Echo-Doppler was normal. Group A had a greater co-morbidity (68\%) than group B (54\%); however, the difference is not statistically significant. Atherosclerosis was discounted as a confounding variable of the clinical data of heart pathology in the cohort, and no patients had a history of angina. The ECG analysis of the cohort showed no signs of ischemia and the cardiac Echo-Doppler was normal. In groups A and B, 6 and 9 women, respectively, had been cholecystectomized; this figure is not exceptional, because in Chile, $55 \%$ of women over age 50 years have a gallbladder pathology (Braghetto et al. 2011). Two men of group A were also cholecystectomized, confirming that this pathology is also common in men. Ten patients had gastrointestinal involvement, three had esophagus achalasia, 1 of group A and 2 of group B, one patient of group B had megacolon, another a colon cancer, one had chronic gastritis, and the last a gastric ulcer. Three patients of group A had chronic gastritis. The electrocardiographic tracing was the basic clue for diagnosis of Chagas cardiomyopathy; 80 abnormalities were observed in the 50 cardiopaths. Sinus bradycardia was the most frequent alteration (23 cases, $28.5 \%$ ); in 15 patients, it was the only alteration of the serial ECG performed (at least three); none of these cases corresponded to athletes or people who do heavy work or received bradycardic vagotonic drugs that could cause this pathology. The eight associated cases correspond to the following: prolonged QTc interval (2), first-degree A-V block and prolonged QTc interval (2), one with LAHB, another with $\mathrm{A}-\mathrm{V}$ first-degree block plus prolonged QTc interval and left ventricular hypertrophy; one case presented sinus bradycardia anterior ischemia and the last ventricular hypertrophy. The prolonged QTc interval is one of the first elements altered in the ECG of chagasic cardiopaths according our experience; this was present in 17 cases $(21.25 \%)$; in three of these it was the only alteration present. In the remaining 14, it was associated with sinus bradycardia (2), ventricular extrasystoles (2), sinus bradycardia plus first-degree A-V block (2), left anterior hemiblock (2), and complete right bundle branch block (2); the remaining four corresponded to left anterior hemiblock plus complete right bundle branch block, two to repolarization abnormalities and the last to systolic bradycardia plus left ventricle hypertrophy and firstdegree A-V block. According to the electrocardiographic alterations, most of the 50 chagasic cardiopaths correspond to grade I, 17 cases ( $34 \%$ ) and grade II, 33 cases (66\%) of the NYHA classification; similar percentages were observed in Brazil (Rassi et al. 2010]. The most frequent electrocardiographic alterations of the group of cardiopaths were sinus bradycardia and prolonged QTc interval. The majority correspond to grades I and II of the NYHA classification. The parasite burden and genotypes of the group with Chagas heart disease and patients with indeterminate Chagas disease were similar. 
Acknowledgments This study was supported by FONDECYT Projects 1120382 and 1100768 . The authors thank Dr. Juan Diego Maya (Pharmacology Program, Biomedical Sciences Institute, Faculty of Medicine, University of Chile) for providing the Tulahuén strain, Dr. Hernán Baeza for the interpretation of the Echo-Doppler, Dra. Catalina Muñoz San Martín for her collaboration, and Gabriela Martínez for the technical assistance.

Conflict of interest The authors declare that they have no conflict of interest.

Open Access This article is distributed under the terms of the Creative Commons Attribution 4.0 International License (http:// creativecommons.org/licenses/by/4.0/), which permits unrestricted use, distribution, and reproduction in any medium, provided you give appropriate credit to the original author(s) and the source, provide a link to the Creative Commons license, and indicate if changes were made.

\section{References}

Andrade JP, Marin-Neto JA, Paola AAV, Vilas-Boas F, Oliveira GMM (2011) Sociedade Brasileira de Cardiologia. Primera Directriz Latinoamericana para el Diagnóstico y el Tratamiento de la Cardiopatía de la Enfermedad de Chagas. Arq Bras Cardiol 97(2): $1-47$

Apt W, Galafé S, Zulantay I, Yuhasz S, Urbina P, Yévenes K, Rodríguez J (2013) Chagas disease: a global neglected disease that require continuous medical education. J Community Med Health Educ 4:260 266

Arenas M, Campos R, Coronado X, Ortiz S, Solari A (2012) Trypanosoma cruzi genotypes of insect vectors and patients with Chagas of Chile studied by means of cytochrome $b$ gene sequencing, minicircle hybridization, and nuclear genepolymorphisms. Vector Borne Zoonotic Dis 12(3):196-205

Barbosa AP, Cardinalli Neto A, Otaviano AP, Rocha BF, Bestetti RB (2011) Comparison of outcome between Chagas cardiomyopathy and idiopathic dilated cardiomyopathy. Arq Bras Cardiol 97:517525

Basile L, Jansa J, Carlier Y (2011) Chagas disease in European countries: the challenge of a surveillance system. Euro Surveill 16:1-10

Basquiera A, Sembaj A, Aguerri A, Omelianiuk M, Guzmán S, Moreno Barral J, Caeiro T, Madoery R, Salomone O (2003) Risk progression to chronic Chagas cardiomyopathy: influence of male sex and of parasitaemia detected by polymerase chain reaction. Heart 89 : $1186-1190$

Basso B, Moretti ER (1984) Detection of Trypanosoma cruzi by hemoculture in patients with chronic Chagas' disease. Medicina (Buenos Aires) 44:41-47

Braghetto I, Jans J, Marambio A, Lasen J, Miranda R, Moyano L, Czende A, Rojas A, Sanhueza A (2011) Correlación ecográficalaparoscópica em colecistitis crónica y aguda. Validación 10 años después. Rev Chil Cirug 63:170-177

Bravo N, Muñoz C, Nazal N, Saavedra M, Martínez G, Araya E, Apt W, Zulantay I (2012) Real-time PCR in faecal samples of Triatoma infestans obtained by xenodiagnosis: proposal for an exogenous internal control. Parasites Vectors 5, e59

Brenière SF, Bosseno MF, Telleria J, Brigitte B, Yacsik N, Noireau F, Alcazar JL, Barnabé C, Winker P, Tibayrenc M (1998) Different behavior of two Trypanosoma cruzi major clones: transmission and circulation in young Bolivian patients. Exp Parasitol 7:285-295

Brenière SF, Bosseno MF, Telleria J, Carrasco R, Vargas F, Yacsik N, Noireau F (1995) Field application of polymerase chain reaction diagnosis and strain typing of Trypanosoma cruzi in Bolivian triatomines. Am J Trop Med Hyg 7:179-184
Briceño-León R (1990) La casa enferma. Sociología de la enfermedad de Chagas. Fondo editorial. Acta científica venezolana. Ediciones Capriles, Caracas, Venezuela

Burgos JM, Altcheh J, Bisio M, Duffy T, Valadares HM, Seidenstein ME, Piccinali R, Freitas JM, Levin MJ, Macchi L, Macedo AM, Freilij H, Schijman AG (2007) Direct molecular profiling of minicircle signatures and lineages of Trypanosoma cruzi bloodstream populations causing congenital Chagas disease. Int J Parasitol 37:1319-1327

Coura J, Viñas P (2010) Chagas disease: a new worldwide challenge. Nature 465:6-7

Cura CI, Lucero RH, Bisio M, Oshiro E, Formichelli LB, Burgos JM, Lejona S, Brusés BL, Hernández DO, Severini GV, Velazquez E, Duffy T, Anchart E, Lattes R, Altcheh J, Freilij H, Diez M, Nagel C, Vigliano C, Favaloro L, Favaloro RR, Merino DE, Sosa-Estani S, Schijman AG (2012) Trypanosoma cruzi discrete typing units in Chagas disease patients from endemic and non-endemic regions of Argentina. Parasitology 139:516-521

Da Matta JA, Aras R Jr, de Macedo CR, da Cruz CG, Netto EM (2012) Stroke correlates in chagasic and non-chagasic cardiomyopathies. PLoS One 7:1-7

De Diego J, Palau M, Gamallo C, Penin P (1998) Are genotypes of Trypanosoma cruzi involved in the challenge of chagasic cardiomyopathy? Parasitol Res 84:147-152

Degrave W, Fragoso SP, Britto C, van Heuverswyn H, Kidane GZ, Cardoso MA, Mueller R, Simpson L, Morel C (1988) Peculiar sequence organization of kinetoplast DNA minicircles from Trypanosoma cruzi. Mol Biochem Parasitol 27:63-70

Duffy T, Bisio M, Altcheh J, Burgos JM, Diez M, Schijman AG (2009) Accurate real-time PCR strategy for monitoring bloodstream parasitic loads in Chagas disease patients. PLoS Negl Trop Dis 3, e419

Elizari M (1999) Chagasic myocardiopathy: historical perspective. Medicina (B Aires) 59:25-40

Gilber S, Alban S, Gobor L, Bescrovaine J, Myiazaki M, Thomaz-Soccol V (2013) Comparison of conventional serology and PCR methods for the routine diagnosis of Trypanosoma cruzi infection. Rev Soc Bras Med Trop 46:310-315

Gomes T, Freitas F, Bezerra C, Lima M, Carvalho-Costa F (2013) Reasons for persistence of dwelling vulnerability to Chagas disease (American trypanosomiasis): a qualitative study in northeastern Brazil. World Health Popul 14:14-21

Hidron A, Gilman R, Justiniano J, Blackstock A, Lafuente C, Selum W, Calderon M, Verastegui M, Ferrufino L, Valencia E, Tornheim J, O'Neal S, Comer R, Galdos-Cardenas G, Bern C (2010) Chagas Disease Working Group in Perú and Bolivia. Chagas cardiomyopathy in the context of the chronic disease transition. PLoS Negl Trop Dis 18(4): 6888

Lee BY, Bacon KM, Bottazzi ME, Hotez PJ (2013) Global economic burden of Chagas disease: computational simulation model. Lancet Infect Dis 13(4):342-348

Luquetti A, Espinoza B, Martínez I, Hernández-Becerril N, Ponce C, Ponce E, Reyes P, Hernández O, López R, Monteón V (2009) Performance levels of four Latin American laboratories for the serodiagnosis of Chagas disease in Mexican sera samples. Mem Inst Oswaldo Cruz 104:797-800

Maguire J, Mott K, Souza J (1982) Clasificación de electrocardiogramas y sistema abreviado de derivaciones para encuestas de poblaciones en relación con la enfermedad de Chagas. Bol San Panam 93:102117

Maya JD, Cassels BK, Iturriaga-Vásquez P, Ferreira J, Faúndez M (2007) Mode of action of natural and synthetic drugs against Trypanosoma cruzi and their interaction with the mammalian host. Comp Biochem Physiol Mol Integr Physiol 146:601-620

Molina-Barríos A, Campos-Estrada C, Lapier M, Duaso J, Kemmerling U, Galanti N, Ferreira J, Morello A, López-Muñoz R, Maya JD (2013) Protection of vascular endothelium by aspirin in a murine model of chronic Chagas' disease. Parasitol Res 112(7):2731-2739 
Moreira O, Ramírez J, Velázquez E, Melo M, Lima-Ferreira C, Guhl F, Sosa-Estani S, Marin-Neto J, Morillo C, Britto C (2013) Towards the establishment of a consensus real-time qPCR to monitor Trypanosoma cruzi parasitemia in patients with chronic Chagas disease cardiomyopathy: a sub-study from the BENEFIT trial. Acta Trop 125:23-31

Morillo C (2013) Infection with Trypanosome cruzi and progression to cardiomyopathy: what is the evidence and is the tide finally turning? Circulation 127:1095-1097

Mosca W, Plaja J, Hubsch R, Cedillos R (1985) Longitudinal study of immune response in human Chagas' disease. J Clin Microbiol 22: $438-441$

Muñoz C, Zulantay I, Apt W, Ortiz S, Schijman A, Bisio M, Ferrada V, Herrera C, Martínez G, Solari A (2013) Evaluation of nifurtimox treatment of chronic Chagas disease by means of several parasitological methods. Antimicrob Agents Chemother 57:4515-4523

NYHA (1994) The Criteria Committee of the New York Heart Association. Nomenclature and Criteria for Diagnosis of Diseases of the Heart and Great Vessels, 9th edn. Little Brown \& Co, Boston, p 253

OPS/OMS (2000) IX Reunión Intergubernamental para la eliminación de Triatoma infestans y la eliminación de la Tripanosomiasis americana por transfusión. Río de Janeiro, Brasil

Pereira J, da Cunha R, Willcox H, Coura J (1990) Development of chronic human chagas cardiopathy in the hinterland of the Paraíba State, Brazil, in a 4.5 year period. Rev Soc Bras Med Trop 23:141-147

Pereira J, Wilcox H, Coura J (1992) The evolution of chronic chagasic cardiopathy. I. The influence of parasitemia. Rev Soc Bras Med Trop 25:101-108

Ramírez J, Guhl F, Rendón L, Rosas F, Marin-Neto J, Morillo C (2010) Chagas cardiomyopathy manifestations and Trypanosoma cruzi genotypes circulating in chronic Chagasic patients. PLoS Negl Trop Dis 4(11), e899

Rassi A, Rezende J, Luquetti A, Rassi A Jr (2010) Chapter 27 Clinical Phases and Forms of Chagas disease, in American Trypanosomiasis. Chagas Disease. One hundred years of Research. Ed Jenny Telleria, Michel Tibayrenc. Elsevier

Rassi A Jr, Rassi A, Marin-Neto J (2009) Chagas heart disease: pathophysiologic mechanisms, prognostic factors and risk stratification. Mem Inst Oswaldo Cruz 104:152-158

Requena-Méndez A, López MC, Angheben A (2013) Evaluating Chagas disease progression and cure through blood-derived biomarkers: a systematic review. Expert Rev Anti Infect Ther 11:957-976

Rodríguez IB, Botero A, Mejía-Jaramillo AM, Marquez EJ, Ortiz S, Solari A, Triana-Chávez O (2009) Transmission dynamics of Trypanosoma cruzi determined by low-stringency single primer polymerase chain reaction and southern blot analyses in four indigenous communities of the Sierra Nevada de Santa Marta, Colombia. Am J Trop Med Hyg 7:396-403

Saavedra M, Zulantay I, Apt W, Martínez G, Rojas A, Rodríguez J (2013) Chronic Chagas disease: PCR-xenodiagnosis without previous microscopic observation is a useful tool to detect viable Trypanosoma cruzi. Biol Res 46:295-298

Salvatella R (2012) Control de la enfermedad de Chagas en las Subregiones de América. XXV Reunión Científica Anual de la Sociedad Argentina de Protozoología y Enfermedades Parasitarias. Rev Arg Sal Publ Vol:13-14

Schenone H (1999) Xenodiagnosis. Mem Inst Oswaldo Cruz 94:289-294

Schijman AG, Altcheh J, Burgos JM, Biancardi M, Bisio M, Levin MJ, Freilij H (2003) Aetiological treatment of congenital Chagas' disease diagnosed and monitored by the polymerase chain reaction. J Antimicrob Chemother 52(3):441-449

Schijman AG, Bisio M, Orellana L, Sued M, Duffy T, Mejia Jaramillo AM, Cura C, Auter F, Veron V, Qvarnstrom Y, Deborggraeve S,
Hijar G, Zulantay I, Lucero RH, Velazquez E, Tellez T, Sanchez Leon Z, Galvão L, Nolder D, Monje Rumi M, Levi JE, Ramirez JD, Zorrilla P, Flores M, Jercic MI, Crisante G, Añez N, De Castro AM, Gonzalez CI, Acosta Viana K, Yachelini P, Torrico F, Robello C, Diosque P, Triana Chavez O, Aznar C, Russomando G, Büscher P, Assal A, Guhl F, Sosa Estani S, DaSilva A, Britto C, Luquetti A, Ladzins J (2011) International study to evaluate PCR methods for detection of Trypanosoma cruzi DNA in blood samples from Chagas disease patients. PLoS Negl Trop Dis 5(1), e931

Schofield C (1994) Triatominae: biology and control. Eurocommunica Publications, West Sussex, 80 pp

Segovia M, Carrasco H, Martínez C, Messenger L, Nessi A, Londoño J, Espinosa R, Martínez C, Mijares A, Bonfante-Cabarcas R, Lewis M, Belkisyolé A, Miles M, Lewellyn M (2013) Molecular epidemiologic source tracking of orally transmitted Chagas disease, Venezuela. Emer Infect Dis 19(7):1098-2101

Silva CP, Del Carlo CH, Oliveira Junior MT, Scipioni A, Strunz-Cassaro C, Ramírez JA, Pereira Barretto AC (2008) Why do patients with chagasic cardiomyopathy have worse outcomes than those with non-Chagasic cardiomyopathy? Arq Bras Cardiol 9:358-362

Silva S de A, Gontijo E, Amaral C (2007) Case-control study of factors associated with chronic Chagas heart disease in patients over 50 years of age. Mem Inst Oswaldo Cruz 102:845-851

Siqueira-Batista R, Meneses L, Storino R (1994) Diagnóstico de laboratorio de la enfermedad de Chagas. Med Costa Rica y Centroamérica XLI 527:69-75

Solari A, Campillay R, Ortíz S, Wallace A (2001) Identification of Trypanosoma cruzi genotypes circulating in Chilean chagasic patients. Exp Parasitol 7:226-233

Tarleton RL, Curran J (2012) Is Chagas disease really the "new HIV/ AIDS of the Americas"? PLoS Negl Trop Dis 6(10), e1861

Umezawa E, Nascimento M, Kesper N Jr (1996) Immunoblot assay using excreted-secreted antigens of Trypanosoma cruzi in serodiagnosis of congenital, acute, and chronic Chagas' disease. J Clin Microbiol 34: 2143-2147

Urbina JA (2015) Recent clinical trials for the etiological treatment of chronic Chagas disease: advances, challenges and perspectives. J Eukaryot Microbiol 62:149-156

Vago A, Andrade L, Leite A, d'Avila Reis D, Macedo A (2000) Genetic characterization of Trypanosoma cruzi directly from tissues of patients with chronic Chagas disease: differential distribution of genetic types into diverse organs. Am J Pathol 156:1805-1809

Valadares H, Pimenta J, de Freitas J, Duffy T, Bartholomeu D (2008) Genetic profiling of Trypanosoma cruzi directly in infected tissues using nested PCR of polymorphic microsatellites. Int J Parasitol 38: $839-850$

Veas F, Breniere SF, Cuny G, Brengues C, Solari A, Tibayrenc M (1991) General procedure to construct highly specific kDNA probes for clones of Trypanosoma cruzi for sensitive detection by polymerase chain reaction. Cell Mol Biol 37(1):73-84

Venegas J, Miranda S, Coñoepan W, Pîchuantes S, Jercic MI, González C, Gajardo M, Apt W, Arribada A, Sánchez G (2010) Microsatellite marker analysis shows differentiation among Trypanosoma cruzi populations of peripheral blood and dejections of Triatoma infestans fed on the same chronic Chagasic patients : microsatellite marker analysis and T. cruzi. Parasitol Res 107(4):855-63

Wen JJ, Nagajyothi F, Machado FS, Weiss LM, Scherer PE, Tanowitz HB, Garg NJ (2014) Markers of oxidative stress in adipose tissue during Trypanosoma cruzi infection. Parasitol Res 113(9):31593165

WHO (2015) Chagas diseases (American trypanosomiasis). http://www. who.int/mediacentre/factsheets/fs340/es/ 